REVIEW ARTICLE

\title{
Gynaecological and Reproductive Health Issues in HIV-Positive Women
}

\author{
Gynécologiques et de santé génésique des femmes séropositives
}

\author{
C. O. Agboghoroma
}

\begin{abstract}
BACKGROUND: Women constitute over 60 percent of the HIVinfected population in sub-saharan Africa. Highly active antiretroviral therapy (HAART) has improved the life span of people living with human immunodeficiency virus (HIV) and acquired immune deficiency syndrome (AIDS). Advances in scientific knowledge and management of the HIV-positive pregnant woman have also led to reduction in the risk of motherto-child transmission (MTCT) of HIV. The gynaecological and reproductive health needs and care of the HIV-positive woman are poorly appreciated, suboptimal and largely neglected, with potential to negatively affect their quality of life and efforts at control of the HIV epidemic.

OBJECTIVE: To review the contemporary gynaecological and reproductive health problems and management of the HIVpositive woman.

METHODS: A review of local and international publications on gynaecology/reproductive health and HIV from indexed/online journals and relevant websites using Pubmed and Google search in the period between 1980 and March 2009.

RESULTS: The HIV-positive woman suffers increased frequency and severity of pelvic infections and cervical premalignant and malignant lesions. Relapses and treatment failures of these conditions are common among these patients. Infertility and contraception are also challenges to the HIVpositive woman. Gynaecological and reproductive health care is an integral part of the comprehensive health care needs of the HIV-positive woman.
\end{abstract}

CONCLUSION: In addition to antiretroviral treatment, HIVpositive women should be provided regular screening for sexually transmitted infections (STIs), cervical cytology, counselling and services for infertility and contraception. Appropriate attention to the gynaecological and reproductive health needs of the HIV-positive woman will improve her general health status and quality of life and contribute to reduction in the incidence of HIV infection. WAJM 2010; 29(3): 135-142.

Keywords: HIV,AIDS, antiretroviral therapy, pelvic infections, cervical cytology, infertility, contraception, reproductive health.

\section{RÉSUMÉ}

CONTEXTE: Les femmes constituent plus de 60 pour cent de la population infectée par le VIH en Afrique sub-saharienne. Très active thérapie antirétrovirale (HAART) a amélioré la durée de vie de personnes vivant avec le virus de l'immunodéficience humaine (VIH) et syndrome d'immuno-déficience acquise (SIDA). Les progrès de la connaissances scientifiques et la gestion du VIH-positifs femme enceinte ont également conduit à la réduction du risque de la mère - À transmission mère-enfant (TME) du VIH. Le gynécologiques et les besoins de santé génésique et les soins aux séropositifs femme sont mal appréciés, et largement sous-optimale négligé, avec un potentiel d'affecter négativement leur qualité de la vie et les efforts de contrôle de l'épidémie de VIH.

OBJECTIF: Passer en revue le contemporain et gynécologiques problèmes de santé génésique et de la gestion de la séropositivité femme.

MÉTHODES: Une revue des publications locales et internationales sur les gynécologie / santé reproductive et du VIH de la indexé / en ligne revues et sites Internet pertinents en utilisant Pubmed et Google Recherche dans la période entre 1980 et Mars 2009.

RÉSULTATS: La femme séropositive souffre augmenté fréquence et la gravité des infections pelviennes et cervicales.

lésions précancéreuses et cancéreuses. Les rechutes et le traitement les échecs de ces conditions sont communs chez ces patients. L'infertilité et la contraception sont aussi des défis à la séropositivité femme. Gynécologiques et les soins de santé de la reproduction est une partie intégrante des soins de santé globale des besoins de la femme VIHpositive.

CONCLUSION: En plus du traitement antirétroviral, séropositifs les femmes devraient être fournis pour un dépistage régulier les infections sexuellement transmissibles (IST), la cytologie du col utérin, services de conseil et de la stérilité et la contraception. l'attention voulue à la gynécologie et la reproduction besoins de santé de la femme VIH-positive permettra d'améliorer sa l'état de santé général et la qualité de vie et de contribuer à réduction de l'incidence de l'infection à VIH. WAJM 2010; 29 (3): 135-142.

Mots-clés: VIH, le SIDA, la thérapie antirétrovirale, les infections pelviennes, cytologie cervicale, l'infertilité, la contraception, la santé génésique.

Department of Obstetrics \& Gynaecology, National Hospital, Abuja, Plot 132 Central District (Phase 2), Abuja, Nigeria Correspondence: Dr. Chris Ovoroyeguono Agboghoroma, Department of Obstetrics \& Gynaecology, National Hospital Abuja Plot 132 Central District (Phase 2), Abuja, Nigeria. Tel: 08023342476 E-mail: agboschris@yahoo.com

Abbreviations: AIDS, Acquired immune deficiency syndrome; ART, Assisted reproductive technology; CPR, Contraceptive prevalence rate; CIN, Cervical intraepithelial neoplasia; HAART, Highly active antiretroviral therapy; HPV, Human papilloma virus; ICSI, Intracytoplasmic sperm injection; IUI, Intrauterine insemination; IVF, In vitro fertilization; MTCT, Mother-to-child transmission; STI, Sexually transmitted infections; TUI, Timed unprotected intercourse. 


\section{INTRODUCTION}

The World Health Organization (WHO) and Joint United Nations Programme on HIV/AIDS (UNAIDS) estimates indicate that at end of 2007, there were about 33.2 million people living with HIV globally and over $67 \%$ were in sub-Saharan Africa. Fifty percent of adults infected globally are women, but the proportion of infected persons who are women in sub-Saharan Africa is over 60\%. ${ }^{1}$ Children (under 15 years) account for 2.5 million of the HIV-infected population and majority $(90 \%)$ were acquired through mother-to-child transmission (MTCT) route. Over $90 \%$ of the yearly 420,000 new infections in children occur in sub-Saharan Africa. In addition to biological factors women in Africa are more vulnerable to HIV infection due to poverty, social inequality and deprivation. The availability and use of HAART has significantly reduced mortality associated with HIV infection and the quality of life of infected persons have also improved. ${ }^{2}$ Advances in scientific knowledge on HIV and management of the HIV-positive pregnant woman have also led to reduction in the risk of MTCT from over $30 \%$ to less than $2 \% .^{3}$ This has necessitated the introduction of screening for HIV among pregnant women and the use of antiretroviral drugs, modifications in obstetrics care and infant feeding in HIVpositive women. ${ }^{4}$

The HIV-positive woman encounters many gynaecological problems. Though, she suffers similar range of gynaecological conditions as the HIV-negative woman, the presence of HIV, level of immune suppression and use of antiretroviral drugs influence the severity, course and response to treatment. Available evidence however, suggests that gynaecological and reproductive health care for the HIVpositive woman is poorly appreciated, suboptimal and largely neglected, with potential to affecting their quality of life. 5,6 This article highlights the contemporary gynaecological problems and reproductive health issues including pelvic infections, lower genital tract malignancy, infertility and contraception in the HIV-positive woman.

\section{SUBJECTS, MATERIALS, AND METHODS}

Several published articles in local and international journals and relevant guidelines of international professional organizations were reviewed. These included published articles in journals cited in Pubmed between 1980 and March 2009 as well as other websites obtained through Google search. These articles were obtained using the key words gynaecology and HIV; reproductive health; and HIV etc. Reference lists from relevant papers were also searched.

\section{Pelvic Infections in HIV-positive Women}

Most pelvic infections are sexually transmitted and are asymptomatic. As over $80 \%$ of HIV infections are similarly acquired through heterosexual contact, both pelvic infections and HIV tend to co-exist and interact, increasing transmission and morbidity in both conditions. There is a $2-5$ fold increased risk of HIV infection in persons who have ulcerative (syphilis, chancroid and genital herpes simplex) and non ulcerative sexually transmitted infections (STIs). ${ }^{7}$ This has been attributed to various biologic mechanisms which include; disruption of mucosal barrier, recruitment and stimulation of HIV susceptible inflammatory cells such as $\mathrm{CD}_{4}$ lymphocytes, Langerhans cells and macrophages, increased genital tract HIV shedding and loss of protective hydrogen peroxide producing lactobacilli which assist in maintaining the acidity of the vagina. ${ }^{8}$ Sexually transmitted infections have been associated with increased viral load and disease progression in HIV-positive women. HIVinduced immune suppression may alter the duration of infectiousness and course of STIs. HIV-positive women co-infected with genital herpes simplex virus are more likely to shed the virus and have frequent recurrences than are HIV-negative women. ${ }^{9}$

Other pelvic infections of importance associated with HIV include vulvovaginal candidiasis, pelvic inflammatory disease (PID) and genital tuberculosis. Vulvovaginal candidiasis tends to be more common, severe and persistent in HIV-positive women. The prevalence of HIV infection among PID patients is high varying from six to $22 \% .^{10}$ The HIV-positive woman with PID usually presents with higher temperature and show greater tendency to development of adnexal mass and tuboovarian abscess which may require surgical intervention. Genital tuberculosis is more common in HIV- positive than HIV-negative women. It results from haematogenous spread as a secondary from other parts of the body in over $90 \%$ of cases. Its prevalence is usually underestimated as efforts are not made to diagnose it even in patients with evidence of primary pulmonary tuberculosis. The recommended drug management for pelvic infections in the HIV-positive woman is essentially same as for the HIV-negative. Treatment failure is, however, more common in HIV-positive women. Careful monitoring of response to treatment is therefore needed to determine when alternative course of management becomes necessary.

The higher prevalence and incidence of pelvic infections among HIV-positive women are a major concern as untreated infections enhance transmission of the virus. It may also lead to infertility, ectopic pregnancy or chronic pelvic pains. There is therefore the need for routine sexual health screening in this group with the aim of early detection and treatment of pelvic infections and other sexual health-related conditions. A detailed sexual history and STI screen including serological investigations for syphilis and hepatitis $\mathrm{B}$ and $\mathrm{C}$; high vaginal swabs to exclude Candida albicans and Trichomonas vaginalis; and endocervical swabs to exclude Neisseria gonorrhoea and Chlamydia trachomatis are recommended. ${ }^{11}$

\section{Cancer of the Cervix and Cervical Intraepithelial Neoplasia (CIN) in Hiv- positive Women}

Cancer of the cervix is the second most common cancer in women after breast cancer worldwide. It is estimated that 470,000 new cases and 270,000 deaths occur globally every year. ${ }^{12}$ Over $80 \%$ of the cervical cancer cases and deaths occur in developing countries, where in many regions it represents the most common female cancer and cause 
of cancer deaths. Premalignant conditions (cervical intraepithelial neoplasia-CIN) of the cervix and invasive cervical cancer behave more aggressively in HIV-positive women - with higher prevalence/ incidence rates, late stage presentation, more treatment failures/recurrences, poorer prognosis and younger mean age (30-40 years as against $44-52$ years in the general population) at presentation. $^{13,14}$ In 1993 the Centre for Disease Control and Prevention (CDC) included invasive cervical cancer as an AIDS-defining condition. ${ }^{13}$ The factors that have been identified as contributing to the altered pathophysiology of cervical lesions in HIV/AIDS patients include infection with human papilloma virus (HPV), the degree of immune suppression, the HIV-RNA viral load and the use or/ non-use of antiretroviral drugs.

Though infection with HPV is common in young sexually active persons in the general population, most infections are cleared naturally by the body's cellmediated immune response. The CDC estimates that the lifetime risk of a sexually active man or woman becoming infected with HPV is 50\%. ${ }^{16}$ Based on their oncogenic potentials, genital HPV has been grouped into two categories of high oncogenic risk (types 16, 18, 45, 31, 33, etc) and low oncogenic risk (types 6,11 , 42, 43, 44 etc). The role of the high risk HPV in the development of CIN and cancer of the cervix is well established. ${ }^{17}$ In about $20 \%$ of women infected with high oncogenic risk HPV, a premalignant lesion develops within 2-4 years. While majority regress, some persist and a few progress to high grade CIN. Invasive cervical cancer develops from a few of such high grade CIN in an average period of 10-15 years. The prevalence rate of HPV in HIV-positive women is much higher than that in HIV-negative women ( $83 \%$ vs. $62 \%$ in a study) ${ }^{18}$. HIV-positive women are more at risk of high-risk HPV and multiple HPV types compared with HIV-negative women. HPV also tends to persist longer in HIV-positive women than in HIV-negative ones, resulting in higher incidence and prevalence of CIN lesions and a more rapid progression to invasive cervical cancer. ${ }^{19}$

The degree of immune suppression is a major factor that predicts the occurrence and severity of cervical lesions. HIV-induced immune suppression leads to impaired cellmediated immunity, with the consequence of inadequate clearance of HPV infections, and spontaneous regression of CIN lesions occur rarely. Persistent HPV and high grade CIN are more common in HIV-positive women with $\mathrm{CD}_{4}$ cell count below 200/ $\mu \mathrm{L}$ compared with those with higher $\mathrm{CD}_{4}$ cell count. ${ }^{20}$ In addition to its effect on immune suppression, the level of HIV infection (measured by the HIV - RNA viral load) regardless of the $\mathrm{CD}_{4}$ count also influences the development of cervical lesions through its modulating effect on HPV. ${ }^{21}$ While the role of HAART on the natural history of CIN remains to be fully elucidated, the increase in risk of cervical disease with low $\mathrm{CD}_{4}$ count and a high HIV-RNA viral load suggest that HAART would have a positive impact. It was shown that regression in CIN among HIVpositive patients on HAART was comparable to that observed in HIVnegative women in a recent study. ${ }^{22}$ However, the effect of HAART on the incidence and prognosis of invasive cervical cancer in HIV-positive patients is yet to be clearly elucidated.

\section{Cervical Screening}

Screening for cervical pre-invasive disease - CIN has been the main strategy to reduce cervical cancer. Cervical cytology has similar validity in both HIVpositive and HIV-negative women. Due to the high prevalence of cervical HPV infection and CIN in HIV-positive women, CIN should be aggressively screened for and treated. Some authorities ${ }^{11}$ recommend that women newly diagnosed of HIV infection should in addition to other general medical care, have cervical cytology at diagnosis, with a follow-up at six months and yearly thereafter. Where resources allow, initial colposcopy is also recommended. Subsequent colposcopy and management of cytologic abnormality / CIN follow standard practice as in HIV-negative women.

\section{Management of Abnormal Cervical Cytology and Cancer of the Cervix}

The management of CIN in the HIVpositive patient is similar to that of HIV- negative. This includes excision or ablation of the lesion, adjunctive medical therapy, hysterectomy and in some situations watchful waiting. Excision or ablation therapy including large loop excision of the transformation zone, cone biopsy, cryosurgery and laser ablation is associated with success rates of $90 \%$ in the general population. ${ }^{23}$ Excisional methods have the advantage of providing specimen for histological diagnosis and free margin determination. Recurrence rates following excision of all grades of CIN are higher in HIV-positive women especially in the presence of immune deficiency. Wright et $\mathrm{al}^{24}$ reported a recurrence rate of $56 \%$ and $10 \%$ respectively among HIV-positive and HIV-negative patients. Topical vaginal 5fluorouracil (5-FU) applied as $2 \mathrm{~g}$ of $5 \%$ cream biweekly for six months duration have been reported to be effective in reducing recurrence rates following excision or ablation procedure for CIN in HIV-positive women. ${ }^{25}$ Watchful waiting may be applicable to patients with CIN 1 with regular follow-up cytology for up to two years while awaiting spontaneous regression. Excisional or ablative therapy becomes necessary if there is progression of cervical abnormality.

The clinical presentation, diagnosis and treatment of cancer of the cervix is essentially the same in both HIV-positive and HIV-negative women. Depending on the cancer stage management may be surgery, radiotherapy, and/or chemotherapy. Treatment outcomes are, however, poorer in HIV-positive women (with high recurrence rates of $88 \%$ in a series). ${ }^{26}$ Close follow-up is necessary after treatment of cancer of the cervix because of the high risk of recurrence.

\section{HPV Testing and HPV Vaccines}

While cervical screening programme has drastically reduced the incidence of cervical cancer in developed nations, same cannot be said of developing countries with little or no organized screening programme. Although HPV testing has been proposed as means of improving cervical screening by some groups, it is currently not recommended in clinical practice. Negative HPV testing may be reassuring, but the long term management of positive testing 
(especially in conjunction with negative cytology) is unclear. The recent development of prophylactic vaccines against HPV (Merck's quadrivalent HPV 6, 11, 16 and $18-$ Gardasil $^{\circledR}$ and Glaxosmithkline's bivalent HPV 16 and 18 - Cervarix ${ }^{\circledR}$ ) may provide an opportunity for reducing the incidence and mortality associated with cervical cancer and other ano-genital conditions in developing countries. The usefulness of these vaccines in the context of HIV infection needs to be fully determined. There is also the need to ensure that the vaccines are accessible and affordable to women, in developing countries, who need them most.

\section{Infertility In HIV-positive Couples}

Higher rates of infertility have been reported among HIV-positive couples compared to the general population. ${ }^{27}$ Infertility in the HIV-positive couple may be voluntary as they may be using condom regularly during sexual intercourse. This is particularly relevant in the context of sero-discordant couples, in order to avoid transmitting the infection to the HIV-negative partner. Reduction in the frequency of sexual activity as a result of chronic ill health and for psychological reasons may also be contributory. HIV-positive females are more prone to tubal/peritoneal factors from increased susceptibility to infections and PID. ${ }^{28}$ Adverse effects on the hypothalamo-pituitary ovarian axis and reduced ovarian reserve have also been suggested. ${ }^{29} \mathrm{HIV}$-positive men tend to have reduced seminal parameters (including count, motility and morphology). ${ }^{30}$ A recent report also suggested that the success rates in assisted reproductive technology (ART) may be reduced in the HIV-positive clients due primarily to poor ovarian response. ${ }^{31}$ Early recourse to fertility assessment and treatment is therefore necessary to optimise the chance of procreation in HIV-infected couples

\section{Management of Infertility in HIV-positive Couples}

The desire for procreation and demand for fertility services among HIVpositive couples have been documented in several reports. ${ }^{32,33}$ In the past, ethical considerations of the welfare of the child and risk of sexual, vertical and nosocomial transmission of HIV limited the offer of fertility services to people living with HIV. However, in recent times due to the effect of HAART and scientific innovation, safe procreation and infertility care can now be offered the HIVpositive couple. Issues of cross contamination of samples and health workers have been addressed through better laboratory and clinical practices. ${ }^{34}$ When indicated, standard investigations, conventional medical / surgical treatment modalities and assisted reproductive technology (ART) used in the management of infertility in the general population also apply in HIV-positive couples. Pre-conception reproductive counselling, STI screen and basic fertility screen including seminal fluid analysis, tests for tubal patency and hormonal assay/ovulation are recommended for all HIV-positive couples who desire procreation. ${ }^{34-36}$

\section{Options for Conception and Fertility Management in HIV-positive Couples}

The options for achieving pregnancy available to the HIV-positive couple depend on whether the male, the female, or both partners are HIV-infected (Table 1). For sero-discordant couples in which the male partner is HIV-positive, the options of safe procreation include timed unprotected intercourse (TUI), donor insemination and sperm washing combined with intrauterine insemination (IUI), in-vitro fertilization (IVF) or intracytoplasmic sperm injection (ICSI). Sero-discordant couples in which the

\section{Table 1: Conception Options in HIV-positive Couples}

\begin{tabular}{ll}
\hline Option & Remarks \\
\hline Timed Unprotected Intercourse & Use Fertile Period \\
& Infected partner on HAAR Viral-load \\
& $<1000$ copies $/ \mathrm{ml}$
\end{tabular}

Sperm Washing

Male-HIV-positive

Insemination with Donor Sperm

Male partner positive, female partner negative Bars genetic parenting in male.

Self insemination with partner's Time insemination at ovulation semen

Adoption Risk-free. Not popular. 
developing countries TUI may however, be the only accessible option to many HIV-positive couples.

\section{Sperm Washing}

Sperm wash is applicable when the male is HIV-infected. The method of sperm wash was pioneered by Semprini et al. ${ }^{41}$ The technique is based on the fact that HIV is present free in seminal fluid and as cell-associated virus in leucocytes and non-spermatozoa cells but is not capable of attaching to, or infecting spermatozoa. It involves the process of sperm migration on density gradient centrifugation, repeated washing of the migrated pellet followed by swim up procedure. Polymerase chain (PCR) test for HIV is performed on aliquot of the final sample as part of quality control to confirm that the final semen product is free of HIV particles. A recent multicentre study from the Centre for Reproductive Assistance Techniques for HIV in Europe (CREAThE) showed that sperm washing procedure is safe and effective in preventing sexual transmission of HIV to uninfected partners ${ }^{42}$. In this report, there were no sero-conversion in the partners who had 2840 IUI, 107 IVF, 397 ICSI and 49 frozen embryo transfers cycles, followed up for over six months after assisted reproduction attempt. The safety of washed sperm has also been attested to by other workers ${ }^{43,44}$ It is recommended that washed sperm be used primarily for IUI in a normal (unstimulated) cycle at the time of ovulation. However, in couples with additional fertility factors, sperm washing may be combined with ovulation induction, IVF or ICSI. ${ }^{36}$ Some authorities prefer sperm washing

Table 2: Eligibility Criteria for the Use of Contraceptive Methods by HIV/AIDS Patients

\begin{tabular}{lccccc}
\hline Method & \multicolumn{5}{c}{ Category } \\
\cline { 2 - 6 } & HIV & AIDS & & HIV/AIDS & \\
& No R $_{\mathbf{x}}$ & ${\text { No } \mathbf{R}_{\mathbf{x}}}$ & NRTIs & NNRT(NVP) & PI(RTV) \\
\hline Male \& Female Condom & 1 & 1 & 1 & 1 & 1 \\
Diaphragm & 3 & 3 & 3 & 3 & 3 \\
Cervical cap & 3 & 3 & 3 & 3 & 3 \\
Spermicides & 3 & 3 & 3 & 3 & 3 \\
Combined oral contraceptives & 1 & 1 & 1 & 2 & 3 \\
Progestin-only pills & 1 & 1 & 1 & 2 & 3 \\
Combined hormonal patch & 1 & 1 & 1 & 2 & 3 \\
Injectable (DMPA) & 1 & 1 & 1 & 1 & 1 \\
Injectable (NET-EN) & 1 & 1 & 1 & 2 & 2 \\
Progestogen Implants & 1 & 1 & 1 & 2 & 3 \\
Cu-IUD (Initiation) & 2 & 3 & 2 & 2 & 2 \\
Cu-IUD (Continuation) & 2 & 2 & 2 & 2 & 2 \\
LNG-IUS (Initiation) & 2 & 3 & 2 & 2 & 2 \\
LNG-IUS (Continuation) & 2 & 2 & 2 & 2 & 2 \\
Male \& Female Sterilization & $\mathrm{A}$ & $\mathrm{S}$ & $\mathrm{A}$ & $\mathrm{A}$ & $\mathrm{A}$ \\
\hline
\end{tabular}

Abbreviations: NRT1s = Nucleoside reverse transciptase inhibitors; NNRTIs = Non-nucleoside reverse transciptase inhibitors; NVP = Nevirapine ; PI = Proteaus inhibitors; RTV = Retonavir ; DMPA = Depot-medroxyprogesterone acetate; NET-EN= Norethisterone enanthate; $\mathbf{C u}-\mathbf{I U D}=$ Copper bearing intrauterine device; LNG-IUS = Levonogestrel intrauterine system; $\mathbf{R}_{\mathrm{x}}=$ Treatment Note: Category 1 = No restriction for use of method; Category $2=$ Method could be used as advantage generally outweighs the theoretical or proven risk; Category $3=$ Use of method not usually recommended unless other more appropriate methods are not available or not acceptable, as the theoretical or proven risk outweighs the advantage of use. Category $4=$ Method should not be used as it is associated with an unacceptable health risk; Category A (accept) = There is no reason to delay sterilization; Category $\mathrm{C}$ (caution) $=$ Performed in routine setting, but with extra preparation and precautions; Category $\mathrm{D}$ (delay) = Procedure is delayed until condition is properly evaluated and/or corrected. Category S (special) = Procedure should be undertaken by an experienced surgeon and staff with proper equipment for anesthesia and back up medical support.

Adapted from $\mathrm{WHO}^{49,50}$ combined primarily with ICSI as the treatment of choice even in the absence of any fertility factor. ${ }^{45,46}$

\section{Insemination with Donor Sperm}

This is applicable when the male partner is HIV-positive but the female is negative. It involves the use of sperm from an HIV-negative donor for artificial insemination. It however, removes the chance of genetic parenting in the male.

\section{Self Insemination with Partner's Semen}

Timed self insemination of partner's semen by an IV infected woman at the time of her ovulation has been used as a risk free means of achieving pregnancy in sero-discordant settings when the male partner is HIV-negative.

\section{Adoption}

Adoption may serve as means of fulfilling the desire for a child in a well adjusted relationship. It is a risk-free measure and may be useful in the context where one or both partners are HIV infected. The child is, however, not a biological product of either partner. The health situation of the couple could be an obstacle in the adoption process. This is not yet a popular option in the African society.

\section{Contraception and HIV}

Contraception is generally required to delay, space and limit child birth. In recent times contraception has been identified as a potential tool in the reduction of the incidence of HIV infection. The WHO and United Nations agencies in 2002 recommended a four pronged strategy to address the issue of paediatric HIV/AIDS. ${ }^{47}$ The strategies include - (i) primary prevention of HIV infection especially in young persons; (ii) prevention of unintended pregnancy in HIV-positive women; (iii) prevention of HIV transmission from an HIV-positive mother to her child, and (iv) provision of treatment, care and support for the HIVpositive woman, her partner and children. The availability and use of contraception is important in addressing the first and second strategies. However, in subSaharan Africa where the prevalence and burden of HIV/AIDS are high, contraceptive prevalence rate (CPR) is 
also low. A recent United Nations report showed that in 2007 the CPR for subSaharan Africa countries was $21.5 \%$ compared with the global average of $63 \% .{ }^{48}$ The low CPR in Africa may be attributed to factors such as high level of illiteracy, religious belief, politics, cultural value and desire for large family, preference for a particular gender and non/poor access to family planning services. The provision of appropriate contraceptive information, counseling and service to the general population including people who are HIV-positive will plays a significant role in reducing the burden of HIV / AIDS in sub-Saharan Africa.

\section{Contraceptive Methods and Use in HIV- positive Patients}

The WHO currently assigns categories (Category 1-4 for nonpermanent methods and category A, C, $\mathrm{D}$ and $\mathrm{S}$ for surgical methods) to the various contraceptive methods based on safety profile. ${ }^{49,50}$ Table 2 shows the categories of the various contraceptive methods in relation to HIV/AIDS and use of antiretroviral dugs. Dual contraception is encouraged in the context of HIV infection. This entails the simultaneous use of condom to reduce the risk of STIs/ viral infection and a more effective contraception such as hormonal, intrauterine device or surgical method.

\section{Barrier Methods}

The barrier methods include the male and female condoms, diaphragm, cervical cap and spermicides. Apart from abstinence, condom is the only recommended method for reduction of sexual transmission of HIV. ${ }^{51}$ In the HIV sero-concordant couples condom use may be necessary not only to prevent pregnancy and STIs but also to prevent HIV drug resistant super infection. In HIV sero-discordant relationships, consistent condom use provides about $80 \%-95 \%$ protection from HIV transmission. ${ }^{52}$ Condom accidents/failures are reported in $1-2 \%$ of users. ${ }^{53}$ Emergency contraception and antiretroviral drugs for post-exposure prophylaxis following sexual exposure (PEPSE) may become necessary in sero-discordant relationship in condom accidents. ${ }^{54}$ The main drawback with male condom is that it requires male participation which may be difficult to negotiate especially in power imbalanced relationship. In such situation the female condom presents an advantage as its use is under the control of the female. The diaphragm and cervical cap covers mainly the cervix leaving most of the vaginal epithelium exposed to semen. The use of diaphragm and cervical cap with nonoxynol-9 can cause vaginal mucosa irritation and ulceration, making them unsafe and therefore not recommended in the context of HIV/AIDS.

\section{Hormonal Contraception}

Hormonal contraceptive methods include - combined oral contraceptive pill, progestogen-only pill, injectable progestogens and progestogen-only sub-dermal implants. The effect of hormonal contraception on HIV progression is not fully known. Available evidence suggests no association between hormonal contraceptive use and changes in HIV RNA viral load and $\mathrm{CD}_{4}$ cell counts in HIV-positive women. ${ }^{55}$ There are controversies as to the effect of hormonal contraceptives on HIV transmission. The available reports are inconsistent regarding whether there is increased risk in transmission. While some reports linked increased risk of HIV transmission with the use of hormonal contraception, ${ }^{56}$ other studies, could not demonstrate such association. ${ }^{57}$

Liver enzyme-inducing drugs including antiretroviral medications and antituberculous drug (rifampicin) that are commonly used in the management of HIV-positive patients may interact with the steroids in hormonal methods with the potential of affecting the efficacy and safety of either of the drugs. ${ }^{58}$ The hormonal contraceptive dose in women on some antiretroviral drugs may need to be increased or alternative contraception provided. There is no restriction on the use of any of the hormonal methods for women who are HIV-positive and are antiretroviral naïve.

Combined Oral Contraceptive Pill (COC) and Progestogen-only Pill (POP)

In current practice the low-dose COC containing 20-35 $\mu$ g ethinylestradiol is generally preferred to the older COC which contains $50 \mu \mathrm{g}$ ethinylestradiol or more. In order to ensure the desired efficacy, COC with higher steroid contents are recommended in HIVpositive women who are using liverenzyme-inducing drugs. ${ }^{11}$ The $\mathrm{POP}$ is an alternative in women who cannot use oestrogen containing pills. However, the occurrence of menstrual irregularity with its use is a major disadvantage in HIVpositive patients.

Injectable Progestogens and Progestogen -only sub-Dermal Implants Depo-medroxyprogesterone acetate (DMPA) is not affected by liver enzymeinducing drugs and hence may be used in patients on various combination of HAART without the loss of its effectiveness. It can be given at the same interval as in uninfected women. The amenorrhoea that may result in up to $35 \%$ of clients is beneficial in reducing the problem of anaemia and HIV spread.

The two main progestin hormonal implants etonogestrel (Implanon ${ }^{\circledR}$ ) and levonorgestrel (Jadelle ${ }^{\circledR}$ ) have noncontraceptive advantage of inducing amenorrhoea with implications, of HIV transmission through reduction in viral shedding. As with most of the hormonal contraception, some antiretroviral drugs interact with the steroids with potential to reduce their efficacy.

\section{Intra-Uterine Devices and Surgical Sterilisation}

Under current WHO guidelines, most HIV infected women can initiate and use IUDs and users who become infected with HIV may continue using the device. However, IUD insertions are not recommended in AIDS patients who have not commenced or not responding to antiretroviral treatment as their reduced immune state makes them more vulnerable to pelvic inflammatory disease. The main disadvantage with the use of copper-bearing intrauterine device (Cu-IUD) compared with the levonorgestrel intrauterine system (LNG-IUS) is an increase in the duration of menstrual bleeding with implications for HIV transmission and anaemia. The potential effect on liver enzymes of levonorgestrel is a factor to be considered in LNG-IUS. 


\section{Surgical Methods - Sterilization}

Vasectomy and bilateral tubal ligation undertaken in males and females respectively are permanent methods of contraception for couples who have completed their family. The procedures do not affect HIV transmission.

\section{Conclusion}

Many gynaecological conditions affect HIV-positive women in greater frequency and severity. Such women are also faced with challenges in safe procreation and contraception. The quality of life of the HIV-positive woman can be enhanced through regular screening and appropriate management of STIs and premalignant lesions of the lower genital tract. Preconception, infertility and family planning counseling / services should be integral parts of care provided to the HIV-positive woman.

\section{ACKNOWLEDGEMENTS}

The author would like to express gratitude to Prof S. A. Sagay of the Department of Obstetrics and Gynaecology, Jos University Teaching Hospital, Jos Nigeria for his critical reading and comments on the article.

\section{REFERENCES}

1. UNAIDS and WHO. AIDS epidemic update: December 2007; Geneva: UNAIDS. 2007

2. Pallela FJ, Delaney KM, Moorman AC, Loveless MO, Fuhrer J, Satten GA et $a l$. Declining morbidity and mortality among patients with advanced human immunodeficiency virus infection. $N$ Engl J Med 1998; 338: 853-60.

3. Townsend C, Cortina-Borja M, Peckham C, Lyall H, de Ruiter A, Tookey P. Very low risk of mother-tochild transmission of HIV in women on HAART achieving viral suppression in the UK and Ireland. AIDS 2008; 22: 973-981.

4. Agboghoroma OC. Management of HIV in Pregnancy: A Clinical Review. Tropical Journal of Obstetrics and Gynaecology 2005; 22: 65-73.

5. Mbu ER, Kongnyuy EJ, Mbopi-Keou FX, Tonye RN, Nana PN, Leke RJI. Gynaecological morbidity among HIV positive pregnant women in Cameroon. Reproductive Health 2008; 5:3. Available at: http://www.reproductivehealth-journal.com/content/5/1/3. Assessed on 6th March 2009.
6. Keiser O, de Tejada BM, Wunder D, Chapuis-Taillard C, Zellweger C, Zinkernagel AS et al. Frequency of gynaecologic follow-up and cervical cancer screening in the Swiss HIV cohort study. Journal of Acquired Immune Deficiency Syndromes 2006; 43: 550-555.

7. Brabin L. Clinical management and prevention of sexually transmitted diseases: A review focusing on women. Acta Trop. 2000; 75: 53-70.

8. Fleming DT, Wasserheit JN. From epidemiological synergy to public health policy and practice; the contribution of other sexually transmitted diseases to sexual transmission of HIV infection. Sex Transm Infect 1999; 75: 3-17.

9. Sebitloane MH. HIV and Gynaecological Infections. Best Practice \& Research Clinical Obstetrics and Gynaecology. 2005; 19: 231-241.

10. Bukusi EA, Cohen CR, Stevens CE, Sinei S, Reilly M, Grieco V, et al. Effects of human immunodeficiency virus 1 infection on microbial origin of pelvic inflammatory disease and on efficacy of ambulatory oral therapy. Am J Obstet Gynecol 1999; 181: 1374-1381.

11. Fakoya A, Lamba H, Mackie N, Nandwani R, Brown A, Bernard EJ et al. British HIV Association, BASHH, FSRH guidelines for the Management of the sexual and reproductive health of people living with HIV infection 2008. HIV Medicine 2008; 9: 681-720.

12. Parkin DM, Bray FI and Devesa SS. Cancer burden in the year 2000. The global picture. Eur J Cancer 2001; 37: 554-566.

13. Danso D, Lyons F and Bradbeer C. Cervical screening and management of cervical intraepithelial neoplasia in HIVpositive women. Int $J$ STD \& AIDS 2006; 17: 579-586.

14. Moodley M, Moodley $\mathrm{J}$ and Kleinschmidt I. Invasive cancer and human papillomavirus virus (HIV) infections: a South African perspective. Int J Gynaecol Cancer 2001; 11: 194197.

15. Centers for Disease Control and Prevention. 1993 Revised classification system for HIV infections and expanded surveillance case definition for AIDS among adolescents and adults. JAMA 1993; 269: 729.

16. Centres for Disease Control and Prevention. Rockville, MD: CDC National Prevention Information Network, 2004.

17. Walboomers KM, Jacobs MV, Manos MM, Bosch FX, Kummer JA, Shah KV et al. Human papillomavirus is a necessary cause of invasive cervical cancer worldwide. J Pathol 1999; 189: 12-19.

18. Sun XW, Kuhn L, Ellerbrock TV, Chiasson MA, Bush TJ, Wright TC Jr. et al. Human papilloma-virus infection in women infected with the human immunodeficiency virus. $N$ Engl J Med 1997; 337: 1343-9.

19. Minkoff H, Feldman J, Dehovitz J, Landesman $S$ and Burk R. A longitudinal study of human papillomavirus carriage in human immunodeficiency virusinfected and human immunodeficiency virus uninfected women. Am J Obstet Gynecol 1998; 178: 982-6.

20. Six C, Heard I, Bergeron C, Orth G, Poveda JD, Zaqury P, et al. Comparative prevalence, incidence and short term prognosis of cervical squamous intraepithelial lesions amongst HIVpositive and HIV-negative women. AIDS 1998; 12: 1047-56.

21. Vernon SD, Hart CE, ReevesWC, Icenogle JP. The HIV-1 tat protein enhances E2-depended human papillomavirus 16 transcription. Virus Res 1993; 27: 133-45.

22. Ahdieh-Grant L, Li R, Levine AM, Massad LS, Strickler HD, Minkoff H, et al. Highly active antiretroviral therapy and cervical squamous intraepithelial lesions in human immunodeficiency virus-positive women. J Natl Cancer Inst 2004; 96: 1070.

23. Burghardt E, Holzer E. Treatment of carcinoma in situ: Evaluation of 1609 cases. Obstet Gynecol 1980; 55: 53945.

24. Wright TC Jr., Koulos J, Schnoll F, Swanbeck J, Ellerbrock TV, Chiasson MA, et al. Cervical intraepithelial neoplasia in women infected with human immunodeficiency virus: outcome after loop electrosurgical excision. Gynecol Oncol 1994; 55: 253-8.

25. Maiman M, Watts DH, Andersen J, Clax P, Merino M, Kendall MA, et al. Vaginal 5-fluorouracil for high-grade cervical dysplasia in human immunodeficiency virus infection: a randomised trial. Obstet Gynecol 1999; 94: 954-61.

26. Chirenje ZM. HIV and cancer of the cervix. Best Practices \& Research Clinical Obstetrics and Gynaecology 2005; 19: 269-276.

27. Fylkesnes K, Ndhlovu Z, Kasumba K, Mubanga Musonda R and Sichone M. Studying dynamics of the HIV epidemic: population-based data compared with sentinel surveillance in Zambia. AIDS 1998; 12: 1227-1234. 
28. Irwin KL, Moorman AC, O'Sullivan MJ, Sperling R, Koestler ME, Soto I, et al. Influence of human immunodeficiency virus infection on pelvic inflamatory disease. Obstet Gynecol 2000; 95: 525-33.

29. Clark R, Mulligan K, Stamenovic E, Chang B, Watts H, Andersen J, et al. Frequency of anovulation and early menopause among women enrolled in selected AIDS clinical trials group studies. J Infect Dis 2001; 184: 13257.

30. Dulioust E, Le Du A, Costagliola D, Gulbert J, Kunstmann JM, Heard I, et al. Semen alterations in HIV-1 infected men. Hum Reprod 2002; 17: 2112-18.

31. Coll O, Fiore S, Floridia M, Giaquinto C, Grosch-Worner I, Guiliano M, et al. Pregnancy and HIV infection: a European concensus on management. AIDS 2002; 16: 1-18.

32. Chen JL, Phillips KA, Kanose DE, Collins RL, Miu A. Fertility desires and intentions of HIV-positive men and women. Fam Plann Perspect 2001; 33: 144-152.

33. Chama C, Morrupa J and Gashau W. Sex and reproduction among HIVinfected people in Maiduguri, Nigeria. Journal of Obstetrics and Gynaecology 2007; 27: 812-815.

34. The Practice Committee of the American Society for Reproductive Medicine. Guidelines for reducing the risk of viral transmission during fertility treatment. Fertil Steril 2008; 90: S156162.

35. The ESHRE Ethics and Law Task Force. Taskforce 8 ethics of medically assisted fertility treatment for HIV positive men and women. Hum Reprod 2004; 19: 2454-6.

36. Gilling-Smith C, Nicopoulos JD, Semprini AE, Frodsham LC. HIV and reproductive care - a review of current practice. BJOG 2006; 113: 869-878.

37. Vernazza PL, Hollander L, Semprini AE, Anderson DJ, Duerr A. HIV -discordant couples and parenthood: how are we dealing with the risk of transmission? AIDS 2006; 40: 635-636.

38. Quinn TC, Wawer MJ, Sewankambo $\mathrm{N}$, Serwadda D, Li C, Wabwre-Mangen $\mathrm{F}$, et al. Viral load and heterosexual transmission of human immunodeficiency virus type 1 . Rakai Project Study Group: N Engl J Med 2000; 342: 921-929.

39. Barreiro P, Del Romero J, Leal M, Hernando V, Asencio R, De Mendoza $\mathrm{C}$, et al. Natural Pregnancies in HIV- serodiscordant couples receiving successful antiretroviral therapy. $J$ Acquir Immune Defic Syndr 2006; 43: 324-326.

40. Luizzi G, Chirianni A, Clementi M, Bagnarelli P, Valenza A, Cataldo PT, et al. Analysis of HIV-1 load in blood, semen and saliva: evidence for different viral compactments in a cross-sectional and longitudinal study. AIDS 1996; 10: 51-56.

41. Semprini AE, Levi-Setti P, Bozzo M, Ravizza M, Taglioretti A, Sulpizio P, et al. Insemination of HIV-negative women with processed semen of HIVpositive partners. Lancet 1992; 340: 1317-1319.

42. Bujan L, Hollander L, Coudert M, Gilling-Smith C, Vucetich A, Guibert J, et al. Safety and efficacy of sperm washing in HIV-serodiscordant couples where the male is infected: results from the European CREAThE network. AIDS 2007; 21: 1909-1914.

43. Savasi V, Fernazzi E, Lanzani C, Oneta M, Parrilla B, Persico T. Safety of sperm washing and ART outcome in $741 \mathrm{HIV}$ 1 sero-discordant couples. Hum Reprod 2006; 22: 772-777.

44. Sauer MV, Chang PL, Establishing a clinical program for human immunodeficiency virus 1-seropositive men to father seronegative children by means of in vitro fertilization with intracytoplasmic sperm injection. American Journal of Obstetrics and Gynaecology 2002; 186: 627-33.

45. Mencaglia L, Falcone P, Lentini GM, Consigli S, Pisoni M, Lofiego V, Guidetti R, Piomboni P, De leo V. ICSI for treatment of human immunodeficiency virus and hepatitis $C$ virus serodiscordant couples with infected male partner. Hum Reprod 2005; 20: 2242-2246.

46. Sauer MV, Wang JG, Douglas NC, Nakhuda GS, Vardhana P, Jovanovic V, Guarnaccia MM. Providing fertility care to men seropositive for human immunodeficiency virus: reviewing 10 years of experience and 420 consecutive cycles of in vitro fertilization and intracytoplasmic sperm injection. Fertil Steril 2009; 91: 2455-60.

47. World Health Organization. Strategic approaches to the prevention of HIV infection in infants. Report of a WHO meeting, Morges Switzerland, 20-22 March 2002. Geneva, WHO, 2002.

48. United Nations Population Division (UNPD). Department of Economic \& Social Affairs. World contraceptive use 2007. New York, United Nations 2008.
Available on-line at: www.un.org/esa/ population/publications/ contraceptive2007. Accessed on March $6^{\text {th }} 2009$.

49. World Health Organization Department of Reproductive Health and Research (WHO/RHR). Medical eligibility criteria for contraceptive use. Third edition. Geneva, WHO. 2004. Available:http:/ www.who.int/reproductive-health/ publications. Accessed on March 3rd 2009

50. World Health Organization Department of Reproductive Health and Research (WHO/RHR). Medical eligibility criteria for contraceptive use. 2008 update. Geneva: WHO, 2008. Available: http:/ www.who.int/reproductive-health/ publications/mec/mec-_update 2008.pdf. Accessed on March $3^{\text {rd }} 2009$

51. World Health Organization. Effectiveness of male latex condoms in protecting against pregnancy and sexually transmitted infections. Geneva: World Health Organization. Fact Sheet No. 243, 2000

52. Holmes KK, Levine R, Weaver M, Effectiveness of condoms in preventing sexually transmitted infections. Bull World Health Organ 2004; 82: 454461.

53. Nakajima ST. Contemporary Guide to Contraception. $2^{\text {nd }}$ edition. Handbooks in Health Care Co. Newton, USA, 2006

54. Fisher M, Benn P, Evans B, Pozniak A, Jones M, MacLean S, Davidson O, Summerside J, Hawkins D. UK Guidelines for the use of post-exposure prophylaxis for HIV following sexual exposure. International Journal of STD \& AIDS 2006; 17: 81-92.

55. Cejtin HEJ. Effect of hormonal contraceptive use on plasma HIV-1 RNA levels among HIV-infected women. AIDS 2003; 17: 1702-4.

56. Wang CC, Reilly M, Kreiss JK. Risk of HIV infection in oral contraceptive pill users: a meta-analysis. J Acquir Immune Defic Syndr 1999; 21: 51-58.

57. Lavreys L, Choham V, Overbaugh J, Hassan W, McClelland RS, Kreiss J, et al. Hormonal contraception and risk of HIV-1 acquisition: results of a 10-year prospective study. AIDS 2004; 695697.

58. Faculty of Family Planning and Reproductive Health Care Clinical Effectiveness Unit. Drug interactions with hormonal contraception. FFPRHC Guidance (April 2005). J Fam Plann Reprod Health Care 2005; 31: 139_ 151. 